\title{
Characterisation of food service establishment wastewater and its implication for treatment
}

\author{
C. Gurd ${ }^{1}$, B. Jefferson ${ }^{1}$ and R. Villa ${ }^{1,21}$ \\ ${ }^{1}$ Cranfield University, College Road, Cranfield - Bedfordshire (UK), MK43 OAL \\ ${ }^{2}$ De Montfort University, Institute of Energy and Sustainable Development, Leicester \\ (UK), LE1 9HB. \\ Email: raffaella.villa@dmu.ac.uk
}

\begin{abstract}
Essential for the selection of a reliable treatment system is the characterisation of the effluent to treat. Kitchen wastewater (KWW) from food service establishments (FSEs) is a strong organic and fat-rich effluent whose characterisation has not been sufficiently addressed. KWW composition is highly variable and linked to the FSE's size, the type of meals prepared and the amount of water used during the cleaning. COD, TSS and fat content (FOG) are the most common parameters found in literature. However, other physical and chemical parameters (e.g. temperature, $\mathrm{pH}$, oil droplets characteristics and trace elements), correlated to commercial kitchen cleaning practices rather than the specific effluent, but equally influential on the treatment efficiencies of both physical and biological methods, have hardly been investigated. A comprehensive characterisation of wastewaters from three food service establishments was used to generate data to support the selection of appropriate FOG mitigation methods. Two novel analytical methods were used to quantify the proportion of emulsified FOG and associated droplet size from different kitchen washing effluents. The results showed that more than $90 \%$ of the FOG from the dishwasher effluent and around $35 \%$ of sink one was emulsified, with droplet sizes less than $100 \mu \mathrm{m}$, well below the removal capabilities of conventional grease interceptors, but easily removed using biological means. From the WW composition results, a formula for predictive modelling was derived to represent average organic matter composition for kitchen wastewater as $\mathrm{C}_{20} \mathrm{H}_{38} \mathrm{O}_{10} \mathrm{~N}$, applicable in remediation processes. These results offer a good starting point for the design, operation, and optimisation of wastewater treatment systems of oil-rich KWW.
\end{abstract}

Keywords: FOG; sewer protection; blockages; bioremediation; grease separation; fatberg

\footnotetext{
${ }^{1}$ Current Address: IESD, De Montfort University, Queen's Building 2.27f, Leicester, LE1 9HB.
} 


\section{Introduction}

Food Service Establishment's (FSE) drains and sewers often suffer from blockages caused by accumulation of fat, oil and grease (FOG), resulting in backup and flooding of wastewater on-site and within the local environment. These problems are generally caused by inadequate on-site pre-treatment of the wastewater and more importantly by failure to take the wastewater characteristics into account when designing the system (e.g. grease interceptors GI, grease removal units $\mathrm{GRU}$, or biological additions). In the UK, these shortcomings currently translate into more than 370,000 sewer blockages every year and into over $£ 100$ million of related clean-up costs for the water industry (Water UK, 2018). Kitchen wastewater (KWW) characteristics vary significantly, depending on the FSE's size, the different type of meal prepared and the amount of water used in the cleaning process (Jacobson et al., 2006). These wastewaters are mainly composed of starch, proteins and fats derived from the food preparation and by alkaline and acidic chemicals from the cleaning of pots, pans and cooking equipment (ovens, woks, fryers, etc.). The generated volume of KWW is also quite variable depending on the different types of restaurant, kitchen set-up and size. Previous studies on FSE wastewater composition have been driven by an interest in either physical or biological remediation. In both processes, oil droplet size plays a pivotal role in their remediation potential. However, so far, this parameter has hardly ever been considered. A detailed classification of the American Petroleum Institute (1990) for oil-water emulsions present in oily wastewater defines particle size, emulsion stability and separation time under gravity for four main categories of particle ranging between 1 and $150 \mu \mathrm{m}$.

According to this classification conventional gravity separators will only effectively remove oil droplets greater than $150 \mu \mathrm{m}$ (American Petroleum Institute, 1990). For example, kitchen clean-up practices often include a dishwasher or an automatic self-washing appliance. The WW discharged from these appliances has been identified as particularly challenging for remediation processes based on physical separation as surfactants, high temperature/pH, and mechanical agitation will yield emulsions with mean droplet sizes less than $20 \mu \mathrm{m}$, classified as chemically stable oil-water emulsions (Chan 2010; Chung \& Young 2013). Moreover, it is also likely that peak discharges of hot dishwasher wastewater in separators will entrain previously separated FOG into the effluent. On the other hand, emulsified lipids are much more bioavailable to microorganisms. Therefore, a combination of the two processes could potentially enhance overall FOG removal by exploiting the different remediation mechanisms. FOG degrading bioadditives are marketed as alternative solutions to grease traps or as enhancements to their efficacy. He et al. (2012) and Tang et al. (2012) reported enhancement in FOG removal at full scale for bioadded systems, whilst Brooksbank et al. (2007) found only one of 'several' commercial microbial supplements capable of significantly degrading fat and oil. Other studies found little difference in efficacy between bioadditives and native microbial populations (Loperena et al., 2006; Mendoza-Espinosa and Stephenson, 1996). Comprehensive data on KWW characteristics is sparse. Kommalapati (2001) reported this lack of information 15 years ago, highlighting the need for data from real high strength wastewater for the design of novel treatment systems. The 
majority of previous studies report only on BOD, COD, FOG, suspended solids and $\mathrm{pH}$. Data from the most comprehensive studies are given alongside results for this study (Table 1). Nutrient concentrations have rarely been investigated despite their crucial importance in organic matter biodegradation. Nitrogen $(\mathrm{N})$ was reported in Wang et al. (2005), and $\mathrm{N}$ and phosphorous (P) in Nisola et al. (2009), although neither paper state the sampling point and therefore whether the effluent was mixed with sewage. Chung \& Young (2013) recorded significantly lower $\mathrm{N}$ concentrations in dishwasher effluent $(3.8 \pm 1.6 \mathrm{mg} / \mathrm{l})$, compared to $30-$ $100 \mathrm{mg} / \mathrm{l}$ in domestic wastewater (Henze et al 2008). No comprehensive data has been found on trace elements. Protein and carbohydrate concentrations are reported in only one study (He, Osborne and de los Reyes, 2012) despite their potential impact on FOG degradation by providing a preferable substrate source (Eltaweel et al. 2005; Ertuğrul et al. 2007; Takaç \& Marul 2008). Finally, literature data on surfactant concentrations is notably lacking despite their potential influence on FOG emulsification and droplet size.

This study aims to address this gap by presenting unique insight into the composition of different wastewaters produced by FSEs, and the degree of FOG emulsification generated by different washing-up techniques using two novel analytical methods. The modified Gerber FOG quantification method described by Gurd et al. (2018) distinguishes between free and emulsified FOG, and provides insight into the relative proportions of easily-separable FOG, which is amenable to removal in Gls, and emulsified FOG that may require alternative techniques such as bioremediation. A novel optical-based method, which enables direct measurement of FOG droplets in complex mixtures (Fairley, 2017), was also employed in tandem to measure FOG droplet size. The results presented in this work will provide a greater understanding of key environmental influences on FOG management strategies with respect to both physical and biological remediation. 
Table 1. Wastewater characteristics from three FSEs $(n=8)$ on Cranfield University campus (this study) in comparison to previous work. Concentrations in $\mathrm{mg} / \mathrm{l}$.

\begin{tabular}{|c|c|c|c|c|c|c|c|c|c|c|c|c|c|c|c|c|c|c|c|c|}
\hline \multirow[b]{2}{*}{ Source } & \multirow[b]{2}{*}{$\begin{array}{l}\text { Sample } \\
\text { point }\end{array}$} & \multirow[b]{2}{*}{$\begin{array}{l}\text { Temp } \\
\left({ }^{\circ} \mathrm{C}\right)\end{array}$} & \multirow[b]{2}{*}{ DO } & \multirow[b]{2}{*}{$\mathrm{pH}$} & \multirow[b]{2}{*}{ SS } & \multirow[b]{2}{*}{ FOG } & \multirow[b]{2}{*}{$\begin{array}{l}\text { FFAs } \\
\text { (wt\%) }\end{array}$} & \multirow[b]{2}{*}{ BOD } & \multirow[b]{2}{*}{ sCOD } & \multirow[b]{2}{*}{ tCOD } & \multirow[b]{2}{*}{$\begin{array}{c}\mathrm{NH}_{4} \\
-\mathrm{N}\end{array}$} & \multirow[b]{2}{*}{ TN } & \multirow[b]{2}{*}{$\begin{array}{c}\mathrm{PO}_{4} \\
-\mathrm{P}\end{array}$} & \multirow[b]{2}{*}{ TP } & \multicolumn{3}{|c|}{ Surfactants } & \multirow[b]{2}{*}{ Protein } & \multirow[b]{2}{*}{$\begin{array}{l}\text { Carbo } \\
\text { hydrate }\end{array}$} & \multirow[b]{2}{*}{$\begin{array}{c}\text { Referen } \\
\text { ce }\end{array}$} \\
\hline & & & & & & & & & & & & & & & $\begin{array}{c}\text { An } \\
\text { (MBAS) }\end{array}$ & $\begin{array}{l}\text { N-ion } \\
\text { (Triton } \\
\mathrm{X}-100)\end{array}$ & Cat & & & \\
\hline $\begin{array}{l}\text { University } \\
\text { campus } \\
\text { restaurant }\end{array}$ & $\begin{array}{l}\text { Potwash } \\
\text { sink }\end{array}$ & $\begin{array}{l}3- \\
46\end{array}$ & $\begin{array}{l}7.4- \\
8.7\end{array}$ & $\begin{array}{l}6.8- \\
7.3\end{array}$ & $\begin{array}{l}217- \\
1791\end{array}$ & $\begin{array}{l}253- \\
1067\end{array}$ & $\begin{array}{l}0.65- \\
4.62\end{array}$ & 856 & $\begin{array}{l}530- \\
2685\end{array}$ & $\begin{array}{l}1482- \\
5363\end{array}$ & $\begin{array}{l}0.8- \\
7.4\end{array}$ & $\begin{array}{l}26- \\
79\end{array}$ & $\begin{array}{l}3.8- \\
12.5\end{array}$ & $\begin{array}{l}4.4- \\
17.1\end{array}$ & $\begin{array}{r}121- \\
817\end{array}$ & $\begin{array}{l}6.2- \\
39.8\end{array}$ & $\begin{array}{l}0.09- \\
0.56\end{array}$ & $\begin{array}{c}158- \\
477\end{array}$ & $\begin{array}{l}202- \\
961\end{array}$ & \multirow{3}{*}{$\begin{array}{l}\text { This } \\
\text { study }\end{array}$} \\
\hline $\begin{array}{l}\text { University } \\
\text { campus } \\
\text { café }\end{array}$ & $\begin{array}{l}\text { Dish- } \\
\text { washer }\end{array}$ & $\begin{array}{l}4- \\
57\end{array}$ & $\begin{array}{l}2.0- \\
6.1\end{array}$ & $\begin{array}{l}11.3- \\
11.8\end{array}$ & $\begin{array}{l}261- \\
1094\end{array}$ & $\begin{array}{l}89- \\
850\end{array}$ & $\begin{array}{c}0.84- \\
1.27\end{array}$ & $\begin{array}{l}1193- \\
2247\end{array}$ & $\begin{array}{l}717- \\
3647\end{array}$ & $\begin{array}{c}2305- \\
4952\end{array}$ & $\begin{array}{l}1.2- \\
5.0\end{array}$ & $\begin{array}{l}32- \\
63\end{array}$ & $\begin{array}{l}4.6- \\
15.3\end{array}$ & $\begin{array}{l}8.8- \\
17.5\end{array}$ & $\begin{array}{r}29- \\
80\end{array}$ & $\begin{array}{l}12.0- \\
26.0\end{array}$ & $\begin{array}{l}0.10- \\
0.51\end{array}$ & $\begin{array}{l}193- \\
363\end{array}$ & $\begin{array}{l}699- \\
3997\end{array}$ & \\
\hline $\begin{array}{l}\text { University } \\
\text { campus } \\
\text { cafe }\end{array}$ & $\begin{array}{l}\text { Mixed } \\
\text { effluent }\end{array}$ & $\begin{array}{c}37- \\
55\end{array}$ & $\begin{array}{l}5.6- \\
7.0\end{array}$ & $\begin{array}{c}10.5- \\
12.0\end{array}$ & $\begin{array}{c}272- \\
912\end{array}$ & $\begin{array}{l}112- \\
494\end{array}$ & $\begin{array}{l}0.83- \\
2.70\end{array}$ & $\begin{array}{l}598- \\
1399\end{array}$ & $\begin{array}{l}309- \\
1790\end{array}$ & $\begin{array}{l}1250- \\
3847\end{array}$ & $\begin{array}{l}0.7- \\
3.4\end{array}$ & $\begin{array}{l}24- \\
65\end{array}$ & $\begin{array}{l}4.7- \\
10.7\end{array}$ & $\begin{array}{l}8.0- \\
28.9\end{array}$ & $\begin{array}{c}12.0- \\
16.0\end{array}$ & $\begin{array}{l}9.1- \\
12.3\end{array}$ & ND & $\begin{array}{l}146- \\
401\end{array}$ & $\begin{array}{l}108- \\
735\end{array}$ & \\
\hline $\begin{array}{l}\text { Chinese } \\
\text { restaurant }\end{array}$ & $\begin{array}{l}\text { Drain } \\
\text { entrance }\end{array}$ & - & - & $\begin{array}{l}6.6- \\
8.0\end{array}$ & $\begin{array}{c}13.2- \\
246\end{array}$ & $\begin{array}{c}120- \\
172\end{array}$ & & $\begin{array}{c}58- \\
1430\end{array}$ & & $\begin{array}{l}292- \\
3390\end{array}$ & & & & & & & & & & \\
\hline $\begin{array}{l}\text { Western } \\
\text { restaurant }\end{array}$ & $\begin{array}{l}\text { Drain } \\
\text { entrance }\end{array}$ & - & - & $\begin{array}{l}6.9- \\
9.5\end{array}$ & $\begin{array}{l}152- \\
545\end{array}$ & $\begin{array}{l}52.6- \\
2100\end{array}$ & & $\begin{array}{l}489- \\
1410\end{array}$ & & $\begin{array}{l}912- \\
3500\end{array}$ & & & & & & & & & & (Chen, \\
\hline $\begin{array}{l}\text { American } \\
\text { fast-food }\end{array}$ & $\begin{array}{l}\text { Drain } \\
\text { entrance }\end{array}$ & - & - & $\begin{array}{l}6.3- \\
7.2\end{array}$ & $\begin{array}{l}68- \\
345\end{array}$ & $\begin{array}{l}158- \\
799\end{array}$ & & $\begin{array}{l}405- \\
2240\end{array}$ & & $\begin{array}{l}980- \\
4240\end{array}$ & & & & & & & & & & $\begin{array}{c}\text { Chen } \\
\text { and Yue, }\end{array}$ \\
\hline $\begin{array}{l}\text { Student } \\
\text { canteen }\end{array}$ & $\begin{array}{l}\text { Drain } \\
\text { entrance }\end{array}$ & - & - & $\begin{array}{l}6.8- \\
8.8\end{array}$ & $\begin{array}{l}124- \\
1320\end{array}$ & $\begin{array}{l}415- \\
1970\end{array}$ & & $\begin{array}{l}545- \\
1630\end{array}$ & & $\begin{array}{l}900- \\
3250\end{array}$ & & & & & & & & & & 2000) \\
\hline UC bistro & $\begin{array}{l}\text { Drain } \\
\text { entrance }\end{array}$ & - & - & $\begin{array}{c}6.0- \\
8.2\end{array}$ & $\begin{array}{c}359- \\
567\end{array}$ & $\begin{array}{l}140- \\
410\end{array}$ & & $\begin{array}{c}451- \\
704\end{array}$ & & $\begin{array}{l}1500- \\
1760\end{array}$ & & & & & & & & & & \\
\hline $\begin{array}{l}\text { Tubitak } \\
\text { restaurant }\end{array}$ & $\begin{array}{l}\text { Not } \\
\text { stated }\end{array}$ & - & - & $\begin{array}{l}6.8- \\
8.3\end{array}$ & $\begin{array}{l}140- \\
2060\end{array}$ & $\begin{array}{l}102- \\
2650\end{array}$ & & & & $\begin{array}{l}305- \\
3325\end{array}$ & & & & & & & & & & $\begin{array}{l}\text { (Gune } \\
\text { s, } \\
2007 \text { ) }\end{array}$ \\
\hline
\end{tabular}




\begin{tabular}{|c|c|c|c|c|c|c|c|c|c|c|c|c|c|c|c|}
\hline $\begin{array}{l}\text { Barbecue } \\
\text { restaurant }\end{array}$ & $\begin{array}{l}\text { Not } \\
\text { stated }\end{array}$ & $\begin{array}{c}15.6 \pm \\
0.3\end{array}$ & & $\begin{array}{c}6.9 \pm \\
0.5\end{array}$ & $\begin{array}{c}1260 \pm \\
61.0\end{array}$ & $\begin{array}{l}894 \pm \\
37.1\end{array}$ & & & $\begin{array}{c}4280 \pm \\
50.7\end{array}$ & & $\begin{array}{c}121 \pm \\
3.1\end{array}$ & $\begin{array}{c}16.2 \pm \\
0.4\end{array}$ & & & $\begin{array}{l}\text { (Nisola } \\
\text { et al. , } \\
2009 \text { ) }\end{array}$ \\
\hline Restaurant & Sewer & & & $\begin{array}{l}6.0- \\
6.2\end{array}$ & $\begin{array}{l}270- \\
450\end{array}$ & $\begin{array}{l}250- \\
520\end{array}$ & & & $\begin{array}{l}2700- \\
3000\end{array}$ & & $\begin{array}{l}68-98 \\
(\mathrm{TKN})\end{array}$ & & & & $\begin{array}{l}\text { (Wang } \\
\text {, Zhou } \\
\text { and } \\
\text { Chua, } \\
\text { 2005) }\end{array}$ \\
\hline Restaurant & $\begin{array}{l}\text { Dish- } \\
\text { washer }\end{array}$ & & & $\begin{array}{l}10.6- \\
11.7\end{array}$ & $\begin{array}{l}43- \\
506\end{array}$ & $\begin{array}{l}173- \\
650\end{array}$ & & & $\begin{array}{l}456- \\
1588\end{array}$ & $\begin{array}{l}0.16- \\
0.76\end{array}$ & $\begin{array}{l}1.63- \\
5.74\end{array}$ & $\begin{array}{l}7.8- \\
10.8\end{array}$ & & & $\begin{array}{l}\text { (Chun } \\
\text { g and } \\
\text { Young, } \\
2013)\end{array}$ \\
\hline $\begin{array}{l}\text { Various } \\
\text { restaurants }\end{array}$ & $\begin{array}{l}\text { Grease } \\
\text { traps }\end{array}$ & & & 6.6 & 1350 & 921 & & & 1400 & 7.56 & 14 & 4.33 & & & $\begin{array}{l}\text { (Shon } \\
\text { et al. , } \\
\text { 2002)) }\end{array}$ \\
\hline $\begin{array}{l}\text { Retirement } \\
\text { home }\end{array}$ & $\begin{array}{l}\text { Gl } \\
\text { influent }\end{array}$ & $\begin{array}{c}20- \\
60\end{array}$ & $\begin{array}{l}1.3- \\
7.1\end{array}$ & $\begin{array}{l}5.2- \\
10.5\end{array}$ & & & & & & & & & $\begin{array}{c}231 \pm \\
653\end{array}$ & $\begin{array}{c}608 \pm \\
827\end{array}$ & $\begin{array}{l}\text { (He, } \\
\text { Osbor }\end{array}$ \\
\hline Restaurant & $\begin{array}{l}\text { Gl } \\
\text { influent }\end{array}$ & $\begin{array}{c}20- \\
52\end{array}$ & $\begin{array}{l}3.0- \\
8.2\end{array}$ & $\begin{array}{l}4.9- \\
11.7\end{array}$ & & $\begin{array}{c}6- \\
13620\end{array}$ & & $\begin{array}{l}1000- \\
2000\end{array}$ & $\begin{array}{l}3000- \\
4000\end{array}$ & & & & $\begin{array}{c}255 \pm \\
641\end{array}$ & $\begin{array}{c}470 \pm \\
888\end{array}$ & $\begin{array}{c}\text { ne and } \\
\text { de los } \\
\text { Reyes, } \\
2012)\end{array}$ \\
\hline $\begin{array}{l}\text { Thai and } \\
\text { Japanese } \\
\text { restaurant }\end{array}$ & $\begin{array}{l}\text { Not } \\
\text { stated }\end{array}$ & & & 6.7 & 1380 & 825 & 7400 & 21300 & & & & & & & \multirow{4}{*}{$\begin{array}{c}\text { (Stoll } \\
\text { and } \\
\text { Gupta, } \\
\text { 1997) }\end{array}$} \\
\hline $\begin{array}{l}\text { Western } \\
\text { restaurant }\end{array}$ & $\begin{array}{l}\text { Not } \\
\text { stated }\end{array}$ & & & 7 & 1100 & 1310 & 9200 & 20900 & & & & & & & \\
\hline $\begin{array}{l}\text { Thai and } \\
\text { western }\end{array}$ & $\begin{array}{l}\text { Not } \\
\text { stated }\end{array}$ & & & 7.3 & 2160 & 730 & 6000 & 20900 & & & & & & & \\
\hline $\begin{array}{l}\text { Asian } \\
\text { CafeCafete } \\
\text { ria }\end{array}$ & $\begin{array}{l}\text { Not } \\
\text { stated }\end{array}$ & & & 7.1 & 2400 & 1110 & 3330 & 8100 & & & & & & & \\
\hline
\end{tabular}




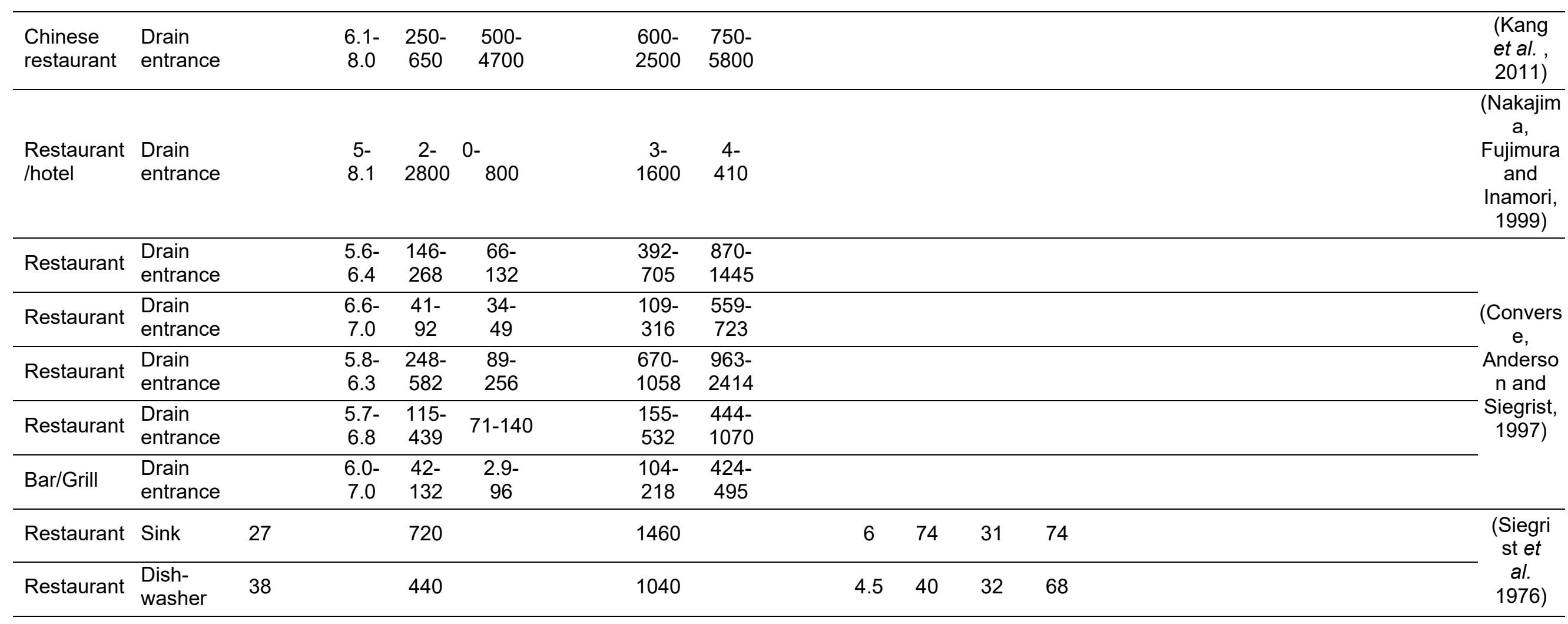




\section{Materials and methods}

All reagents used were purchased from Fisher Scientific unless otherwise stated.

\subsection{Sampling procedure}

Wastewater grab samples were collected from different washing appliance in three FSEs on Cranfield University Campus, UK, (Table 2) serving traditional cafeteria-style food predominantly over a lunch-time period. In each location, washing-up procedures included a potwash sink for manual cleaning of cooking equipment; and a commercial dishwasher for food service items which require thermal sanitisation. Two dishwashers investigated typically operated on a two minute wash cycle, during which detergent and water at approximately $60^{\circ} \mathrm{C}$ is pumped upwards through nozzles to blast food debris from items loaded on to racks. At the end of each cycle three litres of clean water at $>82^{\circ} \mathrm{C}$ is sprayed from above to rinse and achieve heat sterilisation, and approximately three litres of the wash water is discharged. Wash water is recirculated continuously until the entire wash tank $(30-40 \mathrm{I})$ is discharged at the shift end. Ware-washing procedures for the two dishwashers investigated differed. In one establishment, items were loaded on to racks and rinsed with a flexible hose situated over a sink to remove bulk debris prior to loading into the dishwasher. WW samples were taken from an access point in a pipe downstream of the pre-rinse sink and dishwasher, and the timing manipulated to capture both end of dishwasher cycle discharge and pre-rinse water from the sink. Henceforth these samples are identified as 'mixed effluent' (ME). The dishwasher samples (DW) were acquired from a dishwasher typically loaded with dirty items without prior cleaning, grab samples of the DW wastewater were taken directly from the wash tank at the end of a washing cycle. Similarly, grab samples were taken from the potwash sink in a third establishment

Eight sample events occurred over a two-month period. Samples were collected in different days of the week to avoid bias, i.e. busier days or days with a specific menu, between $2-2.30 \mathrm{pm}$ to be representative of heaviest organics-loading associated with end-shift discharge of sinks and dishwasher wash tanks. In total six grab samples were taken for each sampling event in glass bottles with PTFElined lids, 3 for FOG quantification and 3 for the other characteristics. Samples were transported to the lab for preparation within ten minutes and preserved according to relevant Best Practice (BSI Standards, 2012). Temperature was measured at source by a commercial digital temperature probe. All the data from the different FSEs were collated into three groups categorised as sink, mixed effluent and/or dishwasher

A second sampling campaign focussed on characterising FOG with respect to quantifying the proportions of free and emulsified FOG using the novel modified Gerber method, together with emulsified FOG particle size distribution, $\mathrm{pH}$ and surfactants. Eight sample sets were taken from the same potwash sink; and the same dishwasher (minus the pre-rinse water) as the mixed effluent described previously over a period of six weeks. FOG and particle size analysis was performed within 20 minutes of sampling. 
Table 2 Summary of locations, effluent source and characteristics analysed for two FSE wastewater sampling campaigns undertaken on Cranfield University Campus

\begin{tabular}{llll}
\hline Location & Effluent source & $\begin{array}{c}\text { Effluent } \\
\text { notation }\end{array}$ & Characteristics analysed \\
\hline Sampling campaign 1 & & \\
FSE 1 & $\begin{array}{l}\text { Dishwasher and pre- } \\
\text { rinse mixed effluent }\end{array}$ & ME & See Table 1 \\
\hline FSE 2 & Dishwasher tank & DW1 & See Table 1 \\
\hline FSE 3 & Potwash sink & Sink 1 & See Table 1 \\
\hline Sampling campaign 2 & DW2 & $\begin{array}{l}\text { FOG by modified Gerber } \\
\text { method, droplet size, pH } \\
\text { and surfactants }\end{array}$ \\
FSE 1 & Dishwasher tank & DW & FOG by modified Gerber \\
& & Sink 2 & method, droplet size, pH \\
& Potwash sink & &
\end{tabular}

\subsection{Kitchen WW analysis}

All of the first sample sets were analysed, in triplicate, for the following, suspended solids (SS, APHA, 1989), dissolved oxygen (DO), temperature, pH, fat as hexane extractable material (HEM, EPA 1664B, 1999), free fatty acids (Rockwood et al. , 1947) and carbohydrates (Dubois et al. , 1956). In addition to: total chemical oxygen demand (tCOD), and soluble from SS filtrate, ammonia $\left(\mathrm{NH}_{4}\right)$, total nitrogen $(\mathrm{TN})$, phosphate $\left(\mathrm{PO}_{4}\right)$, total phosphorous (TP) and surfactants (anionic, nonionic, cationic), which were all measured using spectroquant cell test kits with a NOVA 60 A Spectroquant photometer (Spectroquant ${ }^{\circledR}$ NOVA 60). Protein concentrations were estimated from the difference between $\mathrm{TN}$ and $\mathrm{NH}_{4}-\mathrm{N}$ multiplied by a standard nitrogen conversion factor of 6.25 .

Micronutrients and heavy metals ( $\mathrm{Na}, \mathrm{K}, \mathrm{Ca}, \mathrm{Mg}, \mathrm{Mn}, \mathrm{Zn}, \mathrm{Mo}, \mathrm{Co}, \mathrm{Cu}$ ) were analysed using Inductively coupled plasma mass spectrometry (ICP-MS) on a dual channel Perkin EImer NexION 350D ICP-MS following microwave digestion as reported by Eduok et al. (2017). Seven additional samples were tested, in triplicate, for biological oxygen demand (BOD 5 , BS EN 1899-1:1998) and COD

2.2.1 Fat quantification by the modified Gerber method

KWW contains high concentrations of detergents, in the presence of which, traditional solvent-based extraction methods for FOG produce high errors (Gurd et al. 2018). A modification of the Gerber method, employed for fat quantification in the dairy industry, was used for FOG quantification (Gurd et al. , 2018). In addition to total FOG quantification, this method allows free FOG floating on the 
surface, and emulsified FOG to be measured separately. In brief, a disc of oiladsorbent material was floated on the WW surface and sample bottles placed in a hot box at $50^{\circ} \mathrm{C}$ for 30 minutes to keep solid fats melted. Adsorbed FOG was eluted from the discs with hexane and determined by gravimetric analysis. Remaining emulsified FOG, and that bound to suspended solids, was extracted by the addition of sodium caseinate, which adsorbs to the emulsified droplets and induces coagulation-flocculation. FOG was isolated by $\mathrm{pH}$ induced coprecipitation and centrifugation, and re-extracted from the solid sediment by a modification to the Gerber milk fat determination method (BSI ISO 2446:2008). Recovery efficiency was previously determined as $100 \pm 5 \%$ in known mixtures of free and emulsified oil (Gurd et al., 2018).

2.2.2 FOG droplet size

Particle size distributions were determined by optical-based sizing conducted on a Flowcam VSI - Portable, with external syringe pump (Meritics, Dunstable,UK). Images were captured at 22 frames per second during 2.5 minutes injection, and FOG droplets distinguished from other particles of food debris through an image processing filter based on defined criteria for circle fit, transparency and edge gradient. Circle fit (CF) was set greater than 0.9, transparency of less than 0.14 and edge gradient (EG) above 100. Diameter was measured on the basis of the mean feret diameter measured across $5^{\circ}$ interval calibrated to a known scale (Fairley, 2017).

\section{Results and discussion}

\subsection{Kitchen WW characterisation}

Although relatively short, the sampling campaign aimed at identifying specific KWW characteristics to improve its treatability related to both physical and biological processes. Different type of restaurants have shown to produce different type of WW (Table 1). However, the scope of this work was to analyse those characteristics produced also by the cleaning processes and common to all waters, which are known to have an impact on the treatment processes. The results of the sampling campaign are in broad agreement with data from previous studies where available (Table 1). Suspended solids, were generally higher than literature values but this may reflect sampling directly at source whereas some sedimentation may have occurred in the pipework in previous studies, FFA content - mean $1.38 \mathrm{wt} \%$ as oleic acid, was similar to the $1-2 \%$ in waste cooking oil (Montefrio et al. , 2010), indicating that cooking had effected a degree of lipid thermal hydrolysis.

A notable difference in $\mathrm{pH}$ was observed between wastewater from the potwash sink (6.8 - 7.3) and the two dishwasher sources (DW1 and ME),10.5 - 12.0due to the high concentrations of sodium hydroxide in dishwasher detergent. Previous studies found typically neutral $\mathrm{pHs}$, apart from values up to 10.4 and 11.7 in Ducoste et al. (2008) and He et al. (2012) respectively, and 10.6 - 11.7 specifically from dishwasher effluent in Chung et al. (2013). Anionic surfactants were extremely high in the potwash sink $(120-820 \mathrm{mg} / \mathrm{l})$ compared to dishwasher effluents $(12-80 \mathrm{mg} / \mathrm{l})$ as a reflection of controlled automatic dishwasher detergent dosing, versus manual application in the sink. Both ranges 
are considerably higher than in domestic discharges: $59 \pm 41 \mathrm{mg} / \mathrm{l}$ and $11.1 \mathrm{mg} / \mathrm{l}$ for a kitchen sink and dishwasher respectively (Friedler, 2004).

(a) Potwash sink

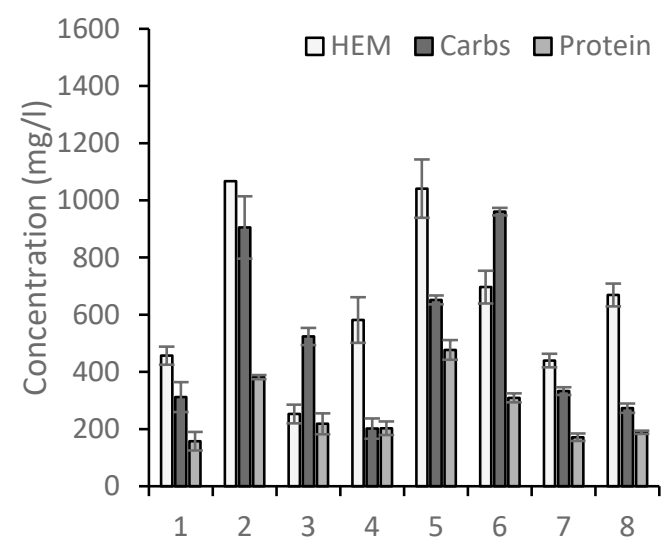

(b) Mixed effluent

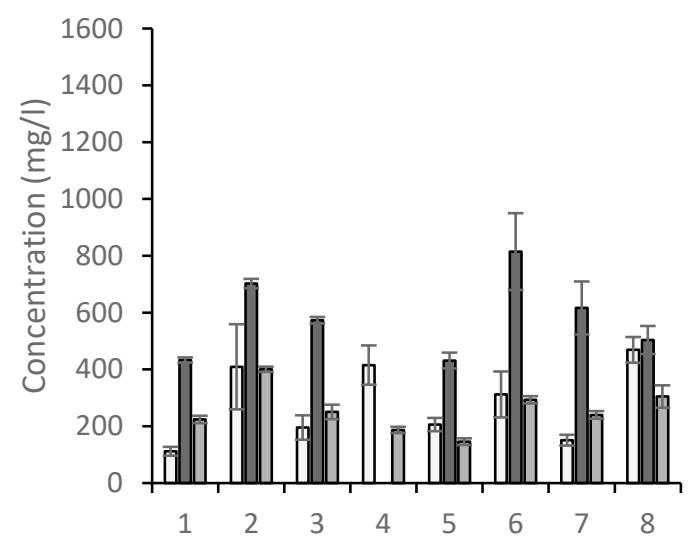

(c) Dishwasher

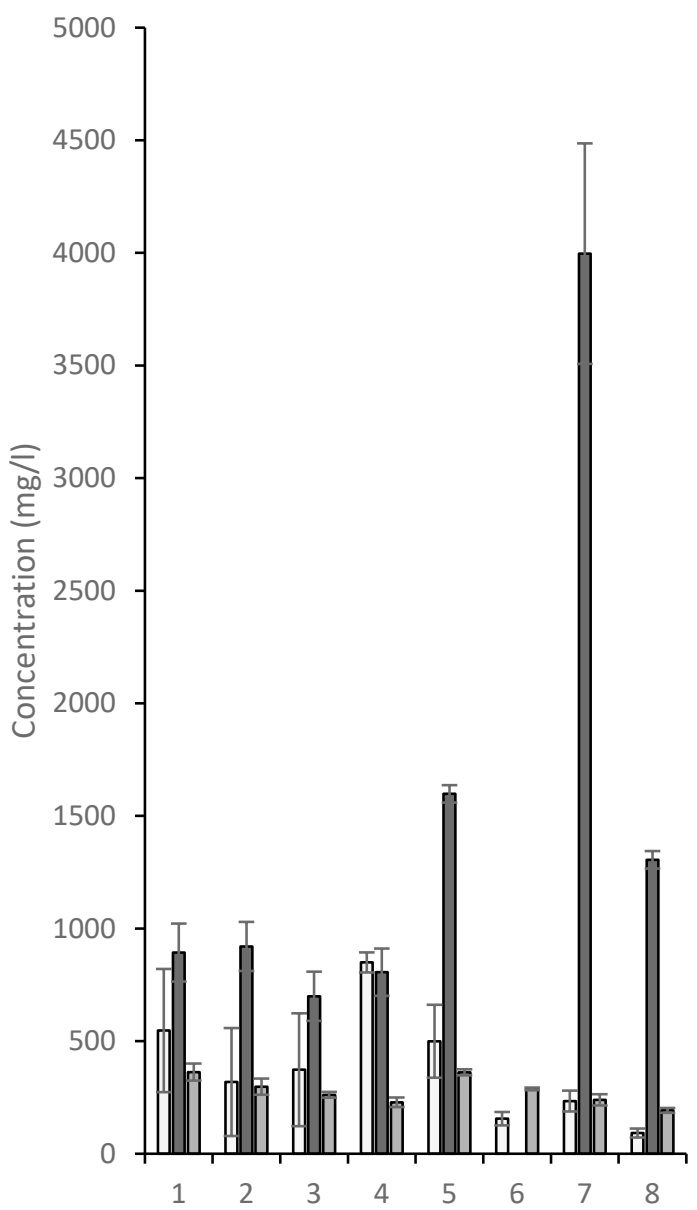

Figure 1. Concentrations of FOG (as HEM), carbohydrate and protein (estimated from TN) in wastewater from a potwash sink (a), mixed effluent (b) and dishwasher (DW1) (c) from three FSEs on Cranfield University Campus. Carbohydrate measurements for samples 4 and 6 in (b) and (c) respectively were not obtained. Data bars represent means of triplicate measurements with error bars as standard deviation.

Domestic sewage is typically rich in ammonia $\left(\mathrm{NH}_{4}\right)$ with concentrations of 20 $75 \mathrm{mg} / \mathrm{l}$ contributing to a range of $30-100 \mathrm{mg} / \mathrm{l}$ for total nitrogen (Henze et al. , 2008). Whilst total nitrogen (TN) in the FSE effluents was similar ( $24-79 \mathrm{mg} / \mathrm{l})$, $\mathrm{NH}_{4}$ concentrations were considerably lower: ranging from $0.7-7.4 \mathrm{mg}-\mathrm{N} / \mathrm{l}$ suggesting that the majority of nitrogen is derived from organic material. Total COD tended to considerably higher concentrations $(1250-5363 \mathrm{mg} / \mathrm{l})$ than ranges in municipal sewage of $500-1200 \mathrm{mg} / \mathrm{l}$ (Henze et al. , 2008) and at the upper end of ranges, or exceeding those previously determined in KWW. Results reported in Figure 1 demonstrate that concentrations of FOG $(92-1067 \mathrm{mg} / \mathrm{l})$, 
carbohydrate $(202$ - $3997 \mathrm{mg} / \mathrm{l})$ and protein $(146$ - $477 \mathrm{mg} / \mathrm{l})$ were highly variable both between and within the different effluent datasets. In general, carbohydrates constituted the largest organic fraction in almost all samples apart from the potwash sink where FOG dominated.

In our samples, on average, carbohydrates constituted the largest organic fraction (54\%), followed by FOG $(29 \%)$, whilst proteinaceous material contributed to only $17 \%$ of organic material. Molar fractions of $\mathrm{C}, \mathrm{H}, \mathrm{O}$ and $\mathrm{N}$ were estimated for each sample using standard molecular formulae for protein $\left(\mathrm{C}_{16} \mathrm{H}_{24} \mathrm{O}_{5} \mathrm{~N}_{4}\right)$, carbohydrate $\left(\mathrm{CH}_{2} \mathrm{O}\right)$, and $\mathrm{FOG}\left(\mathrm{C}_{8} \mathrm{H}_{16} \mathrm{O}\right)$ (Grady et al. , 2011) to derive a stoichiometric formula of $\mathrm{C}_{100} \mathrm{H}_{190 \pm 3} \mathrm{O}_{50 \pm 15} \mathrm{~N}_{4.9 \pm 1.4}$ which simplifies to $\mathbf{C}_{20} \mathbf{H}_{38} \mathbf{O}_{10} \mathbf{N}$. This formula suggests a relatively high carbon to nitrogen $(\mathrm{C}: \mathrm{N})$ ratio of 20 as compared to commonly cited domestic WW compositions. One such formula, $\mathrm{C}_{10} \mathrm{H}_{19} \mathrm{O}_{3} \mathrm{~N}$, reflects a protein-rich composition (Gray, 2004), whilst the composition used in activated sludge models (ASM), $\mathrm{C}_{18} \mathrm{H}_{19} \mathrm{O}_{9} \mathrm{~N}$, derives from roughly equal proportions of protein, carbohydrate and fat (Henze et al. , 2001).

Trace element concentrations (Table 3 ) indicate considerable variability in sodium ( $\mathrm{Na}$ ) and potassium $(\mathrm{K})$ as a reflection of sample source. Elevated $\mathrm{Na}$ in both dishwasher sources (mean $570 \mathrm{mg} / \mathrm{l}$ ) compared to the sink (75 $\mathrm{mg} / \mathrm{l}$ ) reflected sodium hydroxide in both dishwasher detergents. Similarly, higher $\mathrm{K}$ in the mixed effluent (mean $219 \mathrm{mg} / \mathrm{l}$ ), relative to 19.4 and $17.2 \mathrm{mg} / \mathrm{l}$ in the sink and dishwasher respectively, was due to potassium hydroxide in that particular detergent. Relatively lower calcium concentrations in the dishwasher samples (mean $13.6 \mathrm{mg} / \mathrm{l}$ ), reflected employment of a water softener system, which may also have contributed to high $\mathrm{Na}$. Sodium chloride is generally used in all dishwashers and automatic self-washing appliance to soften the water, in hard water areas, or to aid rinsing in soft water ones.

Based on theoretical microbial nutrient requirements suggested by Tchobanoglous and Burton (1991), all samples were severely deficient in Cobalt (Co) and Molybdenum (Mo); and some samples deficient in manganese (Mn) and zinc ( $\mathrm{Zn})$. Burgess et al. (1999) showed the importance of micronutrients in biological treatments. In particular, they showed that manganese and molybdenum, and the combination of calcium with manganese or niacin produced stimulatory effects on the microorganisms and increased the overall microbial metabolic rate. Therefore, micronutrients supplemented directly into the wastewater or in combination with biological additions could also improve biological treatment of FSEs KWW. Phosphorous $(P)$ is also an essential macronutrient and is typically required for biomass synthesis, together with nitrogen, in a $N: P$ ratio of $5: 1$. A ratio of $4( \pm 1): 1$ suggests that most samples might also be deficient in nitrogen. 
Table 3 Trace elements in kitchen wastewater $(n=8)$ from three FSEs on Cranfield University Campus compared to literature data for domestic compositions, and theoretical requirements for microbial growth.

\begin{tabular}{|c|c|c|c|c|c|c|c|c|c|c|c|c|c|}
\hline Source & $\mathrm{Na}$ & $\mathbf{K}$ & $\mathrm{Ca}$ & Mg & $\mathrm{Pb}$ & $\mathrm{Cr}$ & $\mathrm{Fe}$ & $\mathbf{N i}$ & Mn & $\mathrm{Zn}$ & $\mathrm{Cu}$ & Co & Mo \\
\hline & \multicolumn{4}{|c|}{$\mathrm{mg} / \mathrm{L}$} & \multicolumn{9}{|c|}{$\mu g / l$} \\
\hline Sink & $\begin{array}{c}75.0 \pm \\
29.7\end{array}$ & $\begin{array}{c}19.4 \pm \\
8.4\end{array}$ & $43.7 \pm 2.4$ & $\begin{array}{c}5.97 \pm \\
0.57\end{array}$ & & & & & $\begin{array}{c}13.3 \pm \\
12.4\end{array}$ & $\begin{array}{c}91.1 \pm \\
62.1\end{array}$ & $\begin{array}{c}27.0 \pm \\
6.9\end{array}$ & $\begin{array}{c}0.488 \pm \\
0.073\end{array}$ & $\begin{array}{c}0.614 \pm \\
0.465\end{array}$ \\
\hline Mixed effluent & $\begin{array}{c}430 \pm \\
293\end{array}$ & $\begin{array}{c}219 \pm \\
335\end{array}$ & $45.2 \pm 6.7$ & $\begin{array}{c}5.58 \pm \\
0.57\end{array}$ & & & & & $\begin{array}{c}15.1 \pm \\
5.1\end{array}$ & $\begin{array}{l}60.3 \pm \\
20.3\end{array}$ & $\begin{array}{c}36.4 \pm \\
5.6\end{array}$ & $\begin{array}{l}0.480 \pm \\
0.065\end{array}$ & $\begin{array}{c}0.719 \pm \\
0.372\end{array}$ \\
\hline Dish-washer & $\begin{array}{c}714 \pm \\
436\end{array}$ & $\begin{array}{c}17.2 \pm \\
7.5\end{array}$ & $\begin{array}{c}13.6 \pm \\
12.2\end{array}$ & $\begin{array}{c}2.57 \pm \\
1.43\end{array}$ & & & & & $\begin{array}{c}20.5 \pm \\
18.9\end{array}$ & $\begin{array}{c}94.0 \pm \\
61.9\end{array}$ & $\begin{array}{c}24.7 \pm \\
11.7\end{array}$ & $\begin{array}{c}0.455 \pm \\
0.114\end{array}$ & $\begin{array}{c}0.869 \pm \\
0.509\end{array}$ \\
\hline $\begin{array}{l}\text { Domestic kitchen WW } \\
\text { (Eriksson et al. , 2002) }\end{array}$ & $29-180$ & $19-59$ & $13-30$ & $3.3-7.3$ & $62-140$ & $72-130$ & $\begin{array}{l}600- \\
1200\end{array}$ & $<25$ & $31-75$ & $\begin{array}{l}120- \\
1800\end{array}$ & $68-260$ & $<0.12$ & \\
\hline $\begin{array}{l}\text { Theoretical trace } \\
\text { elements requirements } \\
\text { (Tchobanoglous and } \\
\text { Burton, 1991) }\end{array}$ & $10-900$ & $\begin{array}{l}0.8- \\
>3.0\end{array}$ & $0.4-1.4$ & $0.5-5.0$ & $N / A$ & $N / A$ & $\begin{array}{l}100- \\
400\end{array}$ & $\mathrm{~N} / \mathrm{A}$ & $10-50$ & $\begin{array}{l}100- \\
1000\end{array}$ & $10-50$ & $\begin{array}{l}100- \\
5000\end{array}$ & $100-700$ \\
\hline
\end{tabular}




\subsection{Biodegradability potential}

Values of $\mathrm{BOD}_{5}, \mathrm{COD}$ and the measured wastewater organic composition were used to predict the water biodegradability of the KWW samples in different ways. WW biodegradability is often estimated by the ratio of these two values as BOD:COD. Our samples produced a mean value of $0.42 \pm 0.09$, comparable to those reported in other studies (Table 1). A commonly accepted classification defines WW with a BOD:COD ratio $>0.5$ as easily treatable by biological processes, whereas WW with values $<0.3$ contain hard to biodegrade organic matter (Tchobanoglous and Burton, 1991). Our samples therefore lay within the moderately biodegradable range and should be easily biodegraded, which is not always the case for fat-rich KWW.

Biodegradability can also be described by the ratio of carbon, nitrogen and phosphorous (C:N:P) as they are all required for microbial growth in roughly constant proportions. The use of COD values to represent the bioavailability of mixed organic matter (OM) is preferred over the carbon content, to reflect variations in oxidation state of different substrates and thus the amount of electrons available for donation. For example carbohydrate, protein and FOG have COD equivalences of $1.07,1.5$, and $2.88 \mathrm{mgcoD} / \mathrm{mg}$ substrate, respectively (Grady et al. , 2011), yet contain on average 44, 53 and $77 \%$ carbon (Burnham, 2010) yielding COD:C ratios of $2.4,2.8$ and 3.7 respectively. A benchmark COD:N:P ratio of $100: 5: 1$ is generally considered optimum for biological treatment of domestic WW. The COD content of KWW is 3-5 times higher than that reported for greywater (Antonopoulou et al. , 2013). The ratio of chemical oxygen demand (COD):N:P for our KWW samples was estimated at 300:5:1 and 200:3:1 for sink and mixed effluents and 300:4:1 for dishwasher discharges, suggesting a significant $\mathrm{N}$ and $\mathrm{P}$ deficiency for biological degradation in all the samples. Using both real and synthetic grey wastewater, Jefferson et al. (2001), showed that an adjustment of the N:P ratio could generate an increase in oxygen uptake and COD removal. The same authors also suggested that an appropriate $\mathrm{C}: \mathrm{N}$ balance would eliminate the macronutrient-limiting conditions often hindering substrate degradation, such as in the case of fat in KWW. However, Hamza et al. (2019) concluded that nutrient requirements in high organic strength WW (COD $5000 \mathrm{mg} / \mathrm{l}$ ) were less than typical low- and medium-strength systems, with maximum COD removal efficiency (98\%) at COD:N:P 100:1.1:0.4.

\subsection{Physical properties of FOG}

Physical separation relies on droplets size but, notwithstanding the fact that physical separation is one of the main FOG management strategies, to date there is paucity of data related to the size of FOG droplets encountered in FSEs.

One of our previous studies on KWW particle size characterisation using a laser diffraction method reported that KWW from four different FSEs sink (over 5 days) showed median sizes ranges of: 48-56, 9-123, 23-274 and 31-138 $\square \mathrm{m}$. These data related to all components in the KWW, FOG and other debris, the latter in particular were very conspicuous in the sink WW (Barton, 2013). 


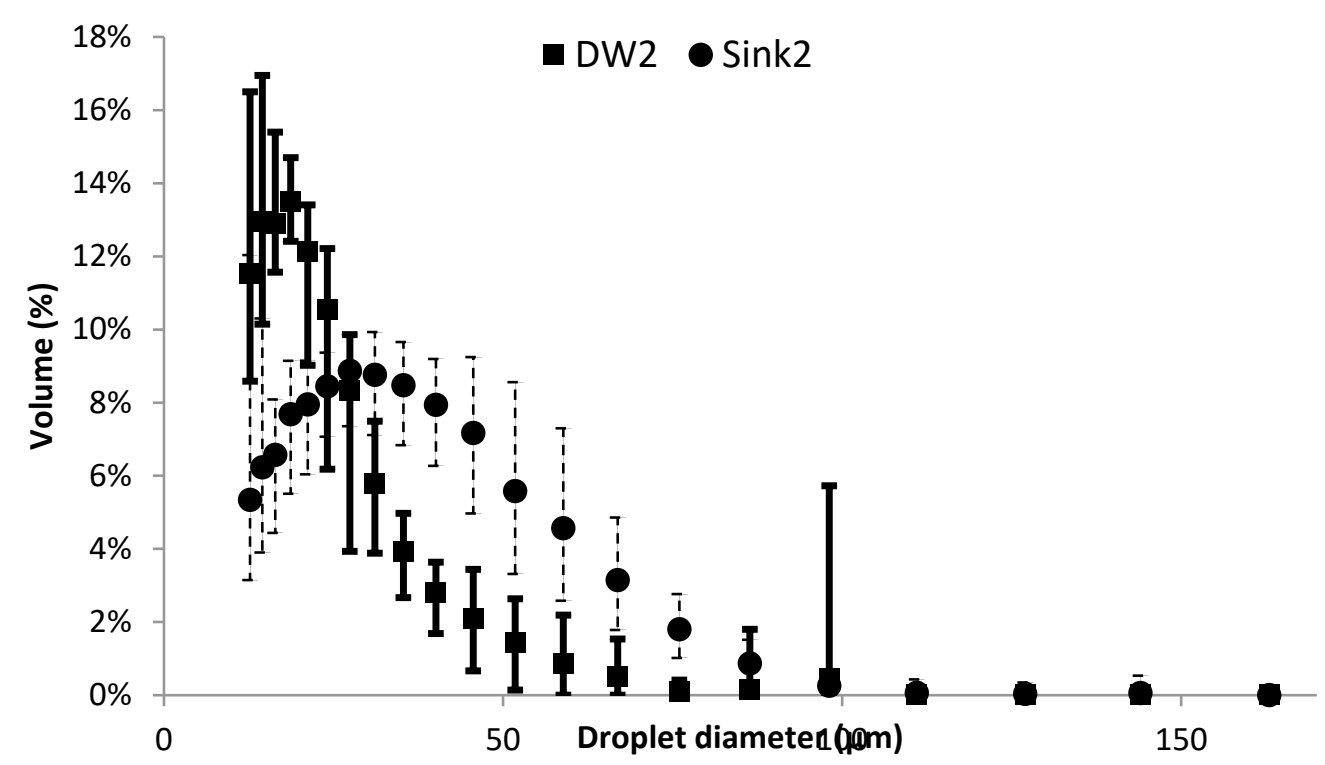

Figure 2. FOG droplet size distribution in sink and dishwasher effluents determined by optical-imaging of a minimum of 1160 droplets per individual measurement. FOG droplet diameter range from11.2 (lower limit of detection) - $163 \mu \mathrm{m}$. Error bars represent ranges from individual triplicate samples aggregated across eight sampling events. $(n=24)$

Table 4. Commercial kitchen wastewater characteristics from a dishwasher and potwash sink. Means \pm standard deviation for $n=8$ samples.

\begin{tabular}{llcc}
\hline Characteristic $(\mathbf{m g} / \mathbf{l})$ & & Dishwasher & Sink \\
\hline FOG & Free & $22 \pm 32$ & $570 \pm 481$ \\
\cline { 2 - 4 } & Emulsified & $291 \pm 90$ & $309 \pm 155$ \\
\cline { 2 - 4 } & & & \\
\cline { 2 - 4 } & Total & $313 \pm 92$ & $879 \pm 583$ \\
\hline Surfactants & Anionic & $2.1 \pm 0.7$ & $180 \pm 98$ \\
\cline { 2 - 4 } & Non-ionic & $24 \pm 8$ & $37 \pm 19$ \\
\hline pH & & $11.58 \pm 0.19$ & $6.76 \pm 0.20$ \\
\hline Median droplet size $(\mu \mathrm{m})$ & & $18 \pm 1$ & $27 \pm 5$ \\
\hline
\end{tabular}

Therefore, in order to discriminate out only the FOG components a second characterisation campaign of KWW was done using an optical based method (Fairley, 2017). FOG concentration data and particle size are summarised in Table 4 , indicating a clear difference in FOG fractionation between free and emulsified phases for the different effluents. Although emulsified FOG concentrations were similar $(291 \pm 90$ and $309 \pm 155 \mathrm{mg} / \mathrm{l}$ in the dishwasher and 
sink respectively), significantly more free FOG was observed in the sink samples $(570 \pm 481 \mathrm{mg} / \mathrm{l})$, such that the emulsified fraction constituted $42 \pm 16 \%$ of total compared to $94 \pm 9 \%$ in DW2. FOG droplet sizes, revealed distributions tending to smaller particle diameters in dishwasher samples (median $18 \pm 1 \mu \mathrm{m}$, mean max $67 \mu \mathrm{m}$ ) compared to the sink (median $27 \pm 5 \mu \mathrm{m}$, mean max $98 \mu \mathrm{m}$ ) (Figure 2).

FOG becomes emulsified through the action of surfactants and mechanical agitation during washing-up - however total detergent surfactant concentrations were, as in the previous characterisation, considerably lower in DW: $26 \pm 8 \mathrm{mg} / \mathrm{l}$ compared to $217 \pm 112 \mathrm{mg} / \mathrm{l}$ in sink (Table 4), and thus could not account for the higher degree of emulsification in the former. It is most likely that a combination of high temperature and $\mathrm{pH}(11.58 \pm 0.19)$, and constant mechanical agitation as wash water is recycled within the dishwasher over a period of hours, generated more stable emulsions associated with smaller FOG droplet sizes.

Handwashing and dishwashing in the sampled kitchens were done using standard commercial detergents, containing both non-ionic and anionic surfactants. Particle size of sunflower oil and SDS (anionic surfactant) or Tween 80 (non-ionic surfactant) at surfactant:oil ratio between 0 and 1 produced very similar particle size distribution after mixing for 1 minute at $10000 \mathrm{rpm}(\mathrm{d}(0.5)$ below $50 \mu \mathrm{m}$ ), e.g. dishwasher equivalent, compared to mixing for 1 minute at 250 rpm (d(0.5) above $100 \mu \mathrm{m})$, e.g. hand-washing (Data not shown, Barton, 2012). Commonly used detergents at the concentrations measured in these kitchen wastewaters are expected to produce similar particle size if subjected to the same mixing regime.

A related point to consider is that different type of cuisine will produce effluents containing different type of oils. Barton (2013) showed that the particle size median formed by the most commonly used cooking oils is very similar. Edible oil with density ranging between 0.89 and 0.91 , when dispersed for 2 minutes at $10,000 \mathrm{rpm}$, produced droplets with median particle size ranging between 29 and $32 \mu \mathrm{m}$ and showed similar removal rate values by gravity separation (45-57\%). It is therefore possible to assume that the size of oil droplets produced by the different washing actives in commercial kitchens is independent of the type of oil used or the type of restaurant that produced them.

\subsection{Implications for FOG management}

Grease interceptors rely on the principle that FOG droplets coalesce and rise, allowing FOG to be skimmed from the surface. According to Stokes' Law, smaller particles have lower rise rates and remain in the aqueous phase for longer time periods. In this study, FOG quantification and droplet size determination were coordinated such that analyses were performed simultaneously for each sample. Thus droplet size and the relative proportions of the free and emulsified FOG fractions are directly linked, representing a temporal 'snapshot' in a dynamic system. These data reflect a sampling-to-measurement time of approximately 45 minutes for both procedures, and is thus comparable to recommended minimum contact times of 30 minutes for passive grease separator design (Tchobanoglous and Burton, 1991). Only $7 \pm 10 \%$ of total FOG resided on the surface in the dishwasher samples. Of the residual emulsified fraction more than $99 \%$ of 
droplets were smaller than $67 \mu \mathrm{m}$ in diameter suggesting that minimal FOG is likely to be removed from dishwasher effluent by physical methods and hence such appliances should not be connected to GI or GRU units. Moreover, the optical method revealed that $76.2 \%$ of emulsified FOG droplets in all the sink samples were $\leq 45 \mu \mathrm{m}$. Barton (2013) measured batch separation rates of FOG as a function of droplet size and density and showed that $92 \%$ removal of the total FOG was observed in 300 seconds for $66 \mu \mathrm{m}$ droplets and $60 \%$ for $44 \mu \mathrm{m}$ droplets. These values increased to $98 \%$ and $90 \%$ respectively after 30 minutes of quiescence time. Based on these datasets, reliance on conventional grease separator devices may allow approximately between 240 and $250 \mathrm{mg} / \mathrm{l} \mathrm{FOG}$ to be discharged to the sewer network. Commercial bioadditives, are a relatively low-cost, non-technical alternative treatment, but their ability to degrade FOG efficiently could be restricted in effluents with high COD:N:P ratios due to limitation of nutrients, and trace elements, required for growth. However, if the two methods were combined a mean of $33 \%$ (150 mg/l) FOG could be easily removed from mixed sink and dishwasher effluents by physical means thereby reducing the carbon load for biological treatment and the nutrient requirements for OM removal, and allowing collected FOG to be used for energy recovery. The adjusted COD:N:P ratio would decrease to 170:4:1 indicating an increase in biodegradability potential. Theoretically, total carbon removal is possible at high COD: $\mathrm{N}$ ratios in association with low microbial yields (Dauner et al., 2001), a crucial determining factor will be whether microbial communities show a particular organic substrate preference, such that FOG removal might be inhibited by the presence of more easily-metabolised carbohydrates and protein. Overall, significant improvements in KWW microbial removal are possible with a simple pre-step of physical removal and nitrogen/phosphorus-balancing. Further improvements could also be achieved with a more complex micronutrients dosing. Jefferson et al. (2001) showed increased COD removal to 130, 240, 150 and $290 \%$ of the control, after dosing cobalt, copper, molybdenum and zinc respectively into real greywater. It is therefore foreseeable that similar increase in COD removal, and hence fat biodegradability, could be attained in KWW through the addition of specific micronutrients (e.g. Co, Mo, Mn and Zn). The latter would also enhance the activity of microbial additions in drains or in separators.

\section{Conclusions}

KWW FOG droplet size exerts a strong influence on removal strategies and is thus a pivotal factor for identifying the best removal technology. Smaller emulsified droplets, harder to remove by physical separation, would be better suitable for microbial degradation, due to their increased surface area and increased solubility. On average $94 \%$ of FOG in dishwasher effluents, and $76 \%$ in a potwash sink comprised of emulsified droplets with diameters below $45 \mu \mathrm{m}$, and, therefore, unlikely to be removed by conventional grease separators devices but more likely to be removed through on-line biological processes.

In brief, physical treatments would be unable to remove around $67 \%$ of total FOG, whereas carbon/nutrient balances suggest that biological treatment efficiency might be limited by nitrogen, phosphorous and trace element deficiency. As such, 
combining physical and biological treatments would allow easily-separable FOG to be removed, thereby reducing carbon loading and associated nutrient limitation on biological treatment.

The findings in this study provide useful information for evaluating the best FOG management strategies for FSEs' KWW. The proposed organic matter composition formula $\mathrm{C}_{20} \mathrm{H}_{38} \mathrm{O}_{10} \mathrm{~N}$ can be used for predictive modelling of biological treatment processes, and the detailed chemical data for designing parameters for biodegradation experiments to reflect more realistic conditions than have been used previously.

\section{Acknowledgments}

The authors gratefully acknowledge financial support from the Engineering and Physical Sciences Research Council (EPSRC) through their funding of the STREAM Industrial Doctorate Centre (Grant no. EP/L015412/1). The authors are grateful for the support of FOG Ltd. All data supporting this study are openly available from the Cranfield University repository as https://doi.org/10.17862/cranfield.rd.7679777.

\section{References}

American Petroleum Institute (1990) Monographs on Refinery Environmental Control- Management of Water Discharges: Design and Operation of Oil-Water Separators.

Barton, P. (2012) Enhancing separation of fats, oils and greases (FOGs) from catering establishment wastewater. Cranfield University. Available at: https://dspace.lib.cranfield.ac.uk/bitstream/handle/1826/8052/Paul Barton The sis 2012.pdf? sequence=1\&isAllowed=y.

Brooksbank, A.M., Latchford, J.W. and Mudge, S.M. (2007) Degradation and modification of fats, oils and grease by commercial microbial supplements, World Journal of Microbiology and Biotechnology, 23(7), pp. 977-985.. DOI: 10.1007/s11274-006-9323-1BSI ISO 2446: (2008) Milk - Determination of fat content - Gerber butyrometers.

BSI Standards (2012) 'BSI Standards Publication Water quality - Sampling Part 3 : Preservation and handling of water samples'.

Burnham, A. K. (2010) Estimating the Heat of Formation of Foodstuffs and Biomass. Livermore, CA (United States). doi: 10.2172/1124948.

Chan, H. (2010) 'Removal and recycling of pollutants from Hong Kong restaurant wastewaters', Bioresource Technology, 101(17), pp. 6859-6867. doi: 10.1016/j.biortech.2010.03.104.

Chen, X., Chen, G. and Yue, P. L. (2000) 'Separation of pollutants from restaurant wastewater by electrocoagulation', Separation and purification technology, pp. 65-76.

Chung, W. and Young, S. (2013) 'Evaluation of a chemical dissolved air flotation system for the treatment of restaurant dishwasher effluent', Canadian Journal of Civil Engineering. NRC Research Press, 40(12), pp. 1164-1172. doi: 
10.1139/cjce-2012-0357.

Converse, J. C., Anderson, D. L. and Siegrist, R. L. (1997) Commercial Wastewater Onsite Treatment and Disposal. Madison, Wisconsin.

Ducoste, J. J. et al. (2008) Assessment of Grease Interceptor Performance (Supplemental Report). Alexandria, VA, USA: Water Environment Research Foundation.

Eltaweel, M. a et al. (2005) 'An organic solvent-stable lipase from Bacillus sp. strain 42', Annals of Microbiology, 55(3), pp. 187-192.

Eriksson, E. et al. (2002) 'Characteristics of grey wastewater', Urban Water. Elsevier, 4(1), pp. 85-104. doi: 10.1016/S1462-0758(01)00064-4.

Ertuğrul, S., Dönmez, G. and Takaç, S. (2007) 'Isolation of lipase producing Bacillus sp. from olive mill wastewater and improving its enzyme activity', Journal of Hazardous Materials, 149(3), pp. 720-724. doi: 10.1016/j.jhazmat.2007.04.034.

Fairley, M. (2017) Fats, oils and Grease management in separators. Cranfield University.

Friedler, E. (2004) 'Quality of Individual Domestic Greywater Streams and its Implication for On-Site Treatment and Reuse Possibilities', Environmental Technology, 25(9), pp. 997-1008. doi: 10.1080/09593330.2004.9619393.

Grady, C. P. L. et al. (2011) Biological wastewater treatment. 3rd edn, Biological wastewater treatment. 3rd edn. Taylor and Francis Group LLC.

Gray, N. F. (2004) Biology of Wastewater Treatment. 2nd edn. London: Imperial College Press (Series on Environmental Science and Management). doi: 10.1142/p266.

Gunes, K. (2007) 'Restaurant Wastewater Treatment by Constructed Wetlands', CLEAN - Soil, Air, Water, 35(6), pp. 571-575. doi: 10.1002/clen.200700142.

Gurd, C. et al. (2018) 'Determination of fats, oils and greases in food service establishment wastewater using a modification of the Gerber method', Water and Environment Journal. John Wiley \& Sons, Ltd. doi: 10.1111/wej.12431.

Hamza, R. A. et al. (2019) 'Optimization of organics to nutrients (COD:N:P) ratio for aerobic granular sludge treating high-strength organic wastewater', Science of The Total Environment. Elsevier, 650, pp. 3168-3179. doi: 10.1016/J.SCITOTENV.2018.10.026.

He, X., Osborne, J. and de los Reyes, F. L. (2012) 'Physico-chemical Characterization of Grease Interceptors with and without Biological Product Addition', Water Environment Research, 84(3), pp. 195-201. doi: 10.2175/106143012X13280358613345.

Henze, M. et al. (2001) Wastewater Treatment: Biological and Chemical Processes. 3rd edn. Berlin Heidelberg: Springer.

Henze, M. et al. (2008) Biological Wastewater treatment: Principles, Modelling and Design. London: IWA Pub.

Kang, J. et al. (2011) 'Photocatalytic pretreatment of oily wastewater from the restaurant by a vacuum ultraviolet/TiO2 system', Journal of Hazardous Materials, 186(1), pp. 849-854. doi: 10.1016/j.jhazmat.2010.11.075. 
Kommalapati, R. R. (2001) A literature review on the evaluation of design parameters for modern grease taps and high strengths wastes. Texas On-site Wastewater Treatment Research Council Project. Prairie View,Texas.

Loperena, L., Saravia, V., Murro, D., Ferrari, M.D. and Lareo, C. (2006) 'Kinetic properties of a commercial and a native inoculum for aerobic milk fat degradation', Bioresource Technology, 97(16), pp. 2160-2165.

Mendoza-Espinosa, L. and Stephenson, T. (1996) 'Grease biodegradation: Is bioaugmentation more effective than natural populations for start-up?', Water Quality International '96 Part 3: Modelling of Activated Sludge Processes; Microorganisms in Activated Sludge and Biofilm Processes; Anareobic Biological Treatment; Biofouling Selected Proceedings of the 18th Biennial Conference of the International, 34(5-6), pp. 303-308.

Montefrio, M. J., Xinwen, T. and Obbard, J. P. (2010) 'Recovery and pretreatment of fats, oil and grease from grease interceptors for biodiesel production', Applied Energy. Elsevier, 87(10), pp. 3155-3161. doi: 10.1016/J.APENERGY.2010.04.011.

Nakajima, J., Fujimura, Y. and Inamori, Y. (1999) 'Performance evaluation of onsitetreatment facilities for wastewater from households, hotels and restaurants', Water Science and Technology. No longer published by Elsevier, 39(8), pp. 8592. doi: 10.1016/S0273-1223(99)00189-4.

Nisola, G. M. et al. (2009) 'Cell Immobilized FOG-Trap System for Fat, Oil, and Grease Removal from Restaurant Wastewater', Journal of Environmental Engineering, 135(9), pp. 876-884. doi: 10.1061/(ASCE)07339372(2009)135:9(876).

Shon, H.-K. et al. (2002) 'Degradation of fat, oil, and grease (FOGs) by lipaseproducing bacterium Pseudomonas sp. strain D2D3', Journal of Microbiology and Biotechnology. Korean Society for Applied Microbiology, 12(4), pp. 583-591.

Stoll, U. and Gupta, H. (1997) 'Management strategies for oil and grease residues', Waste management \& research, 15(1), pp. 23-32. doi: 10.1177/0734242X9701500103.

Takaç, S. and Marul, B. (2008) 'Effects of lipidic carbon sources on the extracellular lipolytic activity of a newly isolated strain of Bacillus subtilis', Journal of Industrial Microbiology \& Biotechnology, 35(9), pp. 1019-1025. doi: 10.1007/s10295-008-0377-y.

Tang, H.L., Xie, Y.F. and Chen, Y.-C. (2012) 'Use of Bio-Amp, a commercial bioadditive for the treatment of grease trap wastewater containing fat, oil, and grease', Bioresource Technology, 124(0), pp. 52-58.

Tchobanoglous, G., Burton, F. L. and Metcalf \& Eddy (1991) Wastewater engineering : treatment, disposal, and reuse. 3rd edn. New York: McGraw-Hill.

Wang, L., Zhou, Q. and Chua, H. (2005) 'Evaluation of a novel integrated bioreactor--AOS system for treating oil-containing restaurant wastewater on site in Hong Kong.', Journal of environmental science and health. Part $A$, Toxic/hazardous substances \& environmental engineering, 40(1), pp. 227-43. 